\section{Maureen Morton}

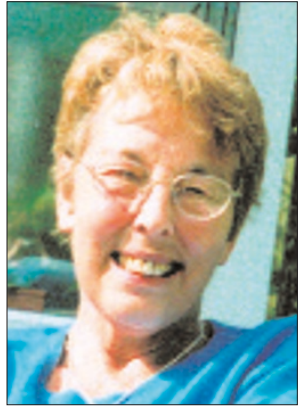

Born December 1937, Maureen entered dental school in Liverpool in 1957 graduating in 1962. She was a popular character within the department and made many friends; she also met her husband, Derek, whom she married in 1963.

Maureen embarked on a career in the community service and stayed with them until she retired in 2000.

Tragedy struck in 1979 when her husband died unexpectedly, leaving her with three young children, the youngest still not even attending school. She stoically set about bringing them up without the slightest hint of bitterness at the situation she found herself in. They all became the citizens one would have expected, like Maureen, considerate and generous.

Apart from her family, Maureen developed many interests and when her domestic commitments had lightened she embarked on following up her keen interest in archaeology and anthropology with expeditions to Egypt, the Amazon and African safaris- to name but a few.

When she was initially diagnosed with cancer, again without any feelings of 'why me?' she approached her treatment with sufficient bravery and strength to conquer it. When we all thought the victory was won, three years later it returned.

\section{When diagnosed with cancer, again} without any feelings of 'why me?' she approached her treatment with sufficient

\section{bravery and strength to conquer it.}

With remarkable bravery she set about putting her remaining life in order and fulfilled several items on her 'must do' list. This included one last trip to Lourdes where she and her husband had over the decades been involved in taking coach loads of people less fortunate than them, to seek solace and comfort. This time it was for herself; deeply religious, this final act seemed to give her the reassurance of facing what was to come with the strength and dignity one had come to expect from her.

She died peacefully in November 2003, surrounded by the people that meant so much to her in life: her family. Her children Luke, Lucy and Alan, her five grandchildren and three remaining brothers and sister will all deeply miss her. The greatest feeling of loss is borne by her mother, who, at 92 has found this tragedy only bearable by the strength and dignity expressed by her daughter in her final days.

Maureen will be missed by everyone who ever knew her, not least me, her youngest brother.

G. Mahony

\title{
Eileen Gertrude McGuire Lindon
}

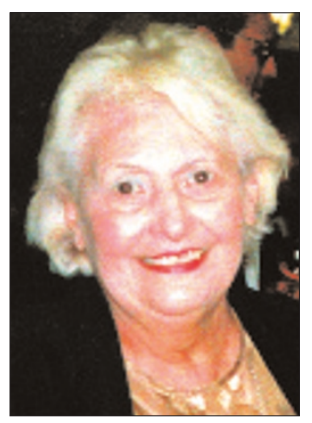

Eileen was born into a medical family and spent her early years in India. Her own studies during the war were curtailed when a stray bomb dropped from an enemy bomber lost somewhere over south-west England devastated Eileen's home and injured her to the extent that she received a permanent $50 \%$ war disability pension.

She recommenced her studies as a dental student at Royal Dental Hospital and qualified in 1947. She was a popular and capable student winning the Delamere Prize for Junior Conservation and three Certificates for Honours in Crown and Bridgework, Operative Dental Surgery and Radiology. She played tennis and hockey for the United Hospital teams, and was particularly proud of having refereed an inter-hospital rugby match.

Eileen especially liked and actively sought the challenges presented in the field of orthodontics, which brought her close to young people whom she could both help and treat. For the next six years she held many posts and took an active part in developing the orthodontic department at The Royal.

She continued her association with the much esteemed Harold Chapman and Dr C. Bowdler-Henry with whom she established one of the first specialised orthodontic NHS practices in Harley Street, London. She was an orthodontic specialist for Middlesex County Council and lectured extensively within the Borough of Ealing District Health Authority, while opening her own practice in 1951 in St. Margarets, Twickenham.

Eileen continued as a senior community dental officer and was also active during the sustained political changes which
Eileen was a remarkable person, who

had much natural ability and was delightful to work with. She had an easy going sense of humour.

took place over the ensuing decades, holding office with the various NHS Authorities, the Local Medical Committee, the Local Dental Committee and the Federation of London Local Dental Committees (Chair 1983-1992).

She joined the British Dental Association soon after qualifying and as a doyenne of dentistry in West London became an influential and stalwart member of the Hounslow and Twickenham Section. She was elected President of the Middlesex and Hertfordshire Branch in 1999.

Eileen had a variety of interests away from dentistry. She became a Justice of the Peace in 1976. She was a life member of the British Association for Cemeteries in South East Asia; the records of her work for this organisation are housed in the British Library. She had a long and caring association with the Martindale School for Cerebral Palsied Children in the London Borough of Hounslow. She travelled extensively and was a particularly keen and knowledgeable gardener.

Eileen was a remarkable person, who had much natural ability and was delightful to work with. She had an easy going sense of humour. All her friends and colleagues will miss her, and all express their deepest sympathy to her children Julia and Peter and her family. 